Preliminary version

\title{
The anticipated effects of EU enlargement: exchange rate volatility, institutions and conditional convergence ${ }^{1}$
}

\author{
Leonardo Becchetti \\ Università Tor Vergata, Roma, Facoltà di Economia, Dipartimento di Economia e Istituzioni, Via \\ di Tor Vergata snc, 00133 Roma. E-Mail : Becchetti@economia.uniroma2.it \\ Iftekhar Hasan \\ Lally School of Management, Rensselaer Polytechnic Institute 518 276-2525, hasan@ rpi.edu \\ Paul Wachtel \\ New York University
}

\begin{abstract}
Improvement (and reduced heterogeneity) of economic policies and institutions and reduced exchange rate volatility are two expected effects arising when candidates develop prerequisites needed to qualify for EU membership.

In this paper we evaluate whether these two effects apply to Eastern European countries by inspecting the volatility of real effective exchange rates (REER) and of different indicators of quality of institutional rules and macroeconomic policies before and after the negotiation period. We finally evaluate the impact of both effects on levels and growth of real per capita GDP.

By comparing dynamics of the above mentioned variables for transition candidates and a group of control countries, including transition non candidates, we find that the positive effects of accession to the EU materialise much before accession and even before the beginning of the negotiating process with significant effects on levels and growth.
\end{abstract}

\footnotetext{
${ }^{1}$ Paper prepared for the 2004 Villa Mondragone Conference. The authors thank O. Knudsen, J. Lothian, G. Piga, L. Sarno, P.L. Scandizzo, M. Taylor and H. Zavarce for their useful comments and suggestions and Antonio de Socio, Serena Troni, Stefania Di Giacomo and Noemi Pace for their precious research assistance. The usual disclaimer applies.
} 


\section{Introduction}

The paper aims to analyze the anticipated impact of accession to EU for a group of transition countries. More specifically, we wonder how the development of prerequisites for accession to the negotiation process, and the negotiation process itself, have contributed to determine changes in the exchange rate volatility and in the quality of institutions and economic policies of "acceding candidates". We focus on these two groups of variables since, consistently with past results in theoretical and empirical literature, we expect a significant contribution from them on levels and on conditional convergence of per capita GDP. We therefore evaluate econometrically whether such impact occurred, and in what magnitude, for transition countries candidates to the EU enlargement. The paper is divided into six parts (including introduction and conclusions).

In the second part we provide an institutional background illustrating the two-way causality nexus between accession and preparation to participate to the negotiating process, on the one side, and the improvement in economic policies and institutional quality of candidates, on the other side. In the third part we briefly summarize the theoretical and empirical support for the impact of these factors on growth. In the fourth section we provide and discuss descriptive evidence on the dynamics of exchange rate volatility and of various indicators of quality of institutions and macroeconomic policies for a subgroup of transition candidates ${ }^{2}$ before and after the start of the negotiating process. In the fifth section we test econometrically the impact of the above mentioned factors on levels and growth of real per capita GDP for a large sample of countries with special focus on the behaviour of transition candidates.

\section{Institutional background: the close links between accession negotiations and the improvement in quality of institutions and economic policies}

A closer look at the structure of the negotiations for candidates to the EU enlargement may help to clarify the link between preparation for EU membership and changes in the two factors (exchange rate volatility and quality of institutions and economic policies) whose impact on levels and growth of per capita GDP will be tested in the next sections of the paper.

From an institutional point of view, the process toward EU accession starts when the potential candidate submits a formal application to join. The European Council, after receiving an opinion from the European Commission, decides whether or not accession negotiations should be opened. More specifically, in the case under analysis, the decision of admitting transition countries to negotiations in the Luxembourg European Council of December 1997 has been based on the potential to fulfill the economic and political conditions known as the "Copenhagen criteria" in the medium term.

Such criteria establish that a prospective member must: $i)$ be a stable democracy, respecting human rights, the rule of law, and the protection of minorities; ii) have a functioning market economy; iii) adopt the common rules, standards and policies that make up the body of EU law. ${ }^{3}$

Accession negotiations started: i) on 31 March 1998 with Hungary, Poland, Estonia, the Czech Republic, Slovenia and Cyprus; ii) on 13 October 1999 with Romania, the Slovak Republic, Latvia, Lithuania, Bulgaria and Malta.

\footnotetext{
${ }^{2}$ We define as transition candidates all those ex communist countries included in the first group of candidates to accession: Czeck Republic, Estonia, Latvia, Lithuania, Slovak Rep., Slovenia, Poland, Hungary. We define as transition candidates all those ex communist countries not in the first group of candidates to accession: Albania, Armenia, Azerbaijan, Belarus, Bulgaria, Croatia, Georgia, Kazakhstan, Kyrgystan, Macedonia, Moldova, Romania, Russia, Tajikistan, Turkmenistan, Ukrain, Uzbekistan.

${ }^{3}$ More detailed info on this point may be retrieved from the following website: http://europa.eu.int/comm/enlargement/enlargement.htm.
} 
On 9th October 2002, the Commission recommended to close negotiations with Cyprus, the Czech Republic, Estonia, Hungary, Latvia, Lithuania, Malta, Poland, the Slovak Republic and Slovenia. Negotiations were effectively concluded with Cyprus, the Czech Republic, Estonia, Hungary, Latvia, Lithuania, Malta, Poland, the Slovak Republic and Slovenia in December 2002. These 10 "acceding countries" are currently set to join on 1st May 2004, while Bulgaria and Romania are expected to do so by 2007.

As specified above, in order to join the Union transition candidates required the fulfillment of the 'Copenhagen criteria'.

To do so, applicants were expected to accept the "acquis", corresponding to laws and rules adopted on the basis of the EU's founding treaties (mainly the treaties of Rome, Maastricht and Amsterdam). The negotiating process leading to the achievement of such goals requires that each applicant country draws up its position on each of the 31 chapters ${ }^{4}$ of the EU acquis, to engage in negotiations. The pace of each negotiation will depend on the speed of each country in converging toward the EU acquis in each of these fields.

Some of these 31 chapters are particularly relevant to our point and to the variable we aim to examine. Chapter 11 deals with the EMU and, even though establishing that "countries cannot adopt the euro upon accession because the Treaty requires that an assessment of the sustainability of the government's financial position be performed before accession", asks for measures of convergence in exchange rate and economic policy which should lead to higher exchange stability and increase the likelihood of future accession to the MU. More specifically, elements that must be implemented in legislation prior to the date of accession, include: i) prohibition of direct financing of the public sector; ii) prohibition of privileged access of the public sector to financial institutions; iii) Central Bank Independence. On the other hand, elements that only have to be complied with from the date of accession include exchange rate and economic policies, co-ordination of economic policies with member states through participation in Community procedures and adherence to the provisions of the Stability and Growth Pact and of the statutes of the ESCB. Other chapters which are especially relevant to our factors are: i) chapter 4 freedom of capital movements; ii) chapter 25 customs union (including in the acquis EU Common Customs Tariff, trade preferences, tariff quotas and tariff suspensions); iii) chapter 5 company law (including protection of industrial property rights).

How far can we trace back candidates effort to be part of the EU ? Formal demands for admission are presented between 1994 and 1996 (see Table 1). The desire and preparation for being part of the EU starts much before. If we look at information on international press we find that the 5th of September 1991 the already known intention of Eastern European countries to apply for admission is confirmed by the fact that Poland, Hungary and the Check Republic ask formally to the EU commissar Andriessen a ticket for participating to the meetings of EU foreign ministers.

Later on, in June 22, 1993 the European Council confirms that all transition countries can be EU members as soon as they will satisfy conditions for admission (the above described Copenhagen criteria).

If we look at formal trade agreements we find that already in 1991 Poland and Hungary sign European Agreements in which they take a formal commitment to closer economic and political integration in exchange of the preferential treatment for their exports. This round of agreements

\footnotetext{
${ }^{4}$ Chapter 1: Free Movement of Goods, Chapter 2: Free Movement for Persons; Chapter 3: Freedom to Provide Services Chapter 4: Free Movement of Capital Chapter 5: Company Law Chapter 6: Competition Policy Chapter 7: Agriculture Chapter 8: Fisheries Chapter 9: Transport Policy Chapter 10: Taxation Chapter 11: EMU Chapter 12: Statistics Chapter 13: Social Chapter 14: Energy Chapter 15: Industrial Policy Chapter 16: SMEs Chapter 17: Science and Research Chapter 18: Education and Training Chapter 19: Telecommunications and Info Chapter 20: Culture and Audiovisual Policy Chapter 21: Regional Policy and Co-ordination Chapter 22: Environment Chapter 23: Consumers and Health Protection Chapter 24: Justice and Home Affairs Chapter 25: Customs Union Chapter 26:External Relations Chapter 27: Common Foreign and Security Policy Chapter 28: Financial Control Chapter 29: Finance and Budgetary Provisions Chapter 30: Institutions Chapter 31: Other Co-ordination of Negotiations and Pre-accession.
} 
follows the previous round (which traces back to 1998) of Trade and Cooperation Agreement which grants transition countries the status of most favored nation.

An important conclusion for our research on the institutional background and on the chronology of the steps undertaken for admission described above is that the improvement in the quality of institutions and economic policies has been both a prerequisite for admission to negotiations and for their successful conclusion for transition candidates. We therefore expect that effects of the process of EU enlargement start well before accession and even before the beginning of the negotiation process. This is because access to negotiations has been conditional to the evaluation of the capacity to fulfill the "Copenhagen criteria" and this capacity was determined on the basis of the progress already achieved on the path of institutional and policy reforms (Henderson, 2000).

\subsection{The state of art on the effects of exchange rate volatility growth}

Theoretical literature developed several models outlining channels through which exchange rate volatility may affect growth, directly or through investment (Caballero-Corbo, 1989; Baum et al., 2001; Froot-Kemplerer, 1989; Serven, 2000). Theoretical predictions on the direction of such relationship are mixed and depend on crucial assumptions on market competitive structure, symmetry/asymmetry of investment adjustment costs and entrepreneurial attitudes toward risk.

In extreme synthesis, the convexity of the profit function may generate the paradoxical effect of a positive effect of exchange rate volatility on investment under perfect competition, risk neutrality and symmetric costs of capital adjustment. Under more realistic assumptions of asymmetric sunk costs of investment, risk aversion and imperfect competition the relationship is clearly reversed.

On the empirical point of view some papers find inconclusive evidence, but a large number of them support the hypothesis of a negative relationship between exchange rate volatility and investment, or, directly, GDP growth. Differences in obtained results depends not only on sample and period specificity, but also on heterogeneous methodological approaches. (Razin-Collins, 1997; Cottani et al., 1990; Dollar, 1992; Ghura and Grennes, 1993; Darby et al., 1999).

The majority of these papers uses simple standard deviations or conditional heteroskedastic measures of bilateral exchange rate volatility or, alternatively, deviations from exchange rate fundamentals. Our argument, which supports the methodological choice explained in the next section, is that bilateral exchange rate measures do not weight and consider the source of instability introduced by additional trading partners and potential diversification effects in countries' export portfolios (Quian-Varangis, 1994). For these reasons a better choice may be to adopt real effective exchange rate (REER) measures which correctly consider the impact of these factors on exchange rate induced instability.

In other terms, we argue that a virtuous country may have low bilateral volatility with a leading currency (i.e. the dollar), but may import instability via volatility of bilateral exchange rates with its regional trade partners. In this perspective the REER may also be viewed as a measure of missing regional integration. 5

\footnotetext{
${ }^{5}$ Edwars-Yeyati (2003) find that terms of trade shocks are amplified in countries with more rigid exchange rate regimes and that, after controlling for other factors, countries with flexible exchange rate regimes grow faster. This result is not in contradiction with our hypothesis on the negative effects of export portfolio volatility on growth. This is because our trade portfolio volatility measure is not the inverse of fixed bilateral exchange rates and therefore its positive effect on growth cannot be in contradiction with the negative effect on growth of fixed exchange rates.

The example of Argentinean crisis may illustrate it. Argentina had a currency board with the United states and therefore was classified as a highly rigid exchange rate regime. The problem though is that some of its main trading partners (i.e. Brazil) had with her flexible exchange rates and the country suffered from their devaluation. It may therefore happen that a country classified with rigid exchange rates has a high export portfolio volatility. Bagella-Becchetti-Hasan (2004) confirm this point showing that, in many cases, countries classified with flexible exchange rates may have relatively lower export portfolio volatility than countries classified with rigid exchange rates.
} 


\subsection{The state of art on the effects of quality of institutions and economic policies on growth}

The literature analyzing the role of the quality of institutions and economic policies on growth is so wide that we just make reference to a few contributions that may be useful to understand the ranking of this variable vis-à-vis other factors affecting growth and/or conditional convergence.

Rodrik (1999, 2002) and Frankel (2002) consider that the success of market based economies crucially hinges on the presence of good institutions. The most important of them are institutions which defend property rights, fight corruption, support macroeconomic stabilization and promote social cohesion. By applying the stochastic frontier approach to country level production functions Klein and Lu (2003) observe that institutions and policies which promote political stability increase proximity to the efficient frontier. Esfahani-Ramirez (2003) find a significant link between quality of institutions, infrastructure and growth.

Recent surveys and comparative evaluations of the impact of different factors of conditional convergence highlight that quality of economic policies and institutions play a dominant role among them. Among 87 different factors affecting growth surveyed by Durlauf and Quah (1998) in their empirical studies, institutions (Rodrik, 2000; Barro-Sala-i-Martin, (1995,1996, 2002) or, more specifically, financial institutions (Pagano, 1993; King-Levine, 1997) play a crucial role together with human capital (Mankiw-Romer-Weil, 1992). Other factors such as the government sector (Hall-Jones, 1997), social and political stability (Alesina-Perotti, 1994) and corruption (Mauro, 1995) all appears as different facets of the quality of institutions and economic policies.

In a direct evaluation of the relative significance of different factors, Sala-y-Martin (2002) finds that institutional quality is one of the most robust. The impact of institutions on growth with specific reference to transition countries is tested by De Melo, Denizer and Gelb (1996) and by Fischer, Sahay and Vegh (1996a).

In the next two sections we provide and comment descriptive and econometric evidence to test whether the behaviour of acceding candidates to EU enlargement during and before the negotiation period is consistent with the above mentioned predictions from the literature .

\section{Descriptive evidence}

In this section we provide and describe evidence on the dynamics of the two factors which we expect to be affected by application and development of prerequisites needed to enter the EU.

More specifically, we collect information on real effective exchange rates and quality of institutions and economic policies for transition candidates and a control group including also transition non candidates.

Our measure of exchange rate volatility is a real effective exchange rate measure which models any country as having a portfolio of assets represented by its relationships with trade partners.

Hence, the variance of the portfolio $\sigma_{p, i}{ }^{2}$ of assets for the $\mathrm{i}$-th country having trade relationships with $\mathrm{j}(\mathrm{j}=1, . ., \mathrm{N})$ partners, may be written as:

$\sigma_{\mathrm{p}, \mathrm{i}}{ }^{2}=\sum_{j} x^{2}{ }_{j} \sigma^{2}{ }_{j}+2 \sum_{h<k} x_{h} x_{k} \sigma_{h k}$

with $\sigma_{j}^{2}$ being the variance of the return of the $j$-th asset, or the rate of return of the bilateral exchange rate with the $\mathrm{j}$-th partner, $\mathrm{x}_{\mathrm{j}}$ the share of export to the $\mathrm{j}$-th partner out of the $\mathrm{i}$-th country total export, $\sigma_{h k}$ the covariance between bilateral exchange rate returns of the $i$-th country with partners $\mathrm{h}$ and $\mathrm{k}$. Following (Bagella-Becchetti-Hasan 2003) we take into account that contributions to the REER of small trading partners tend to be negligible. 
This is why we decide not to include additional trade partners when one of the following constraints is hit: i) a number of trading partners higher than 7; ii) a cumulative export share higher than 60 percent; iii) an individual partner share smaller than 2 percent. $^{6}$

Results on the dynamics of REER from 1998 to 2001 for different group of countries, including transition candidates, are presented in figure 1 and Table 3 and may be conveniently divided into two phases: i) a first phase of extreme REER volatility (from 1988 to 1996); ii) a second phase of sharp reduction in REER volatility (from 1997 to 2001). More specifically, we may divide the high volatility period into three parts: ia) the first from 1998 to the middle of 1990; ib) the second from the middle of 1990 to the end of 1993; iii) the third from the end of 1993 to the end of 1996 . $^{7}$

Desai (1998) analyses the high REER volatility period (1990-1996). He identifies the root of these turbulences in the disequilibrium between undervalued nominal exchange rates and their PPP measures. Furthermore, Brada-Drabek (1998) find a strong correlation between REER volatility and changes in trade policies in transition countries. More specifically, these show that peaks of REER appreciations are associated with trade restrictions and viceversa.

If we consider that some steps need to be taken by candidates before starting negotiations and that on 31 March 1998, accession negotiations were started with six applicant countries - Hungary, Poland, Estonia, the Czech Republic, Slovenia and Cyprus - we may see a significant correspondence between the ongoing negotiating process and its requirements and the dynamics of the REER volatility. ${ }^{8}$ At the end of our sample period (2001) the REER volatility of our group of countries is only 5 percent of the 1995 level. No other areas or group of countries exhibit a similar reduction of exchange rate volatility.

The above mentioned sequence of prerequisites needed to start negotiations and of achievements needed to lead negotiation to the final outcome of accession to the EU clearly outline a complex two-way relationship between our selected variables (exchange rate volatility and quality of institutions and economic policies) and the process toward EU enlargement (only countries which do relatively better can start the process and, at the same time, the process itself leads to an improvement of the observed variables). The two-way relationship clearly includes, on the basis of what we have explained here and above, an impact of the desire to participate and effective participation to the process on real effective exchange rates and on the improvement of the quality of institutions and economic policies and on the reduction of the REER volatility.

To measure this second group of variables our indicator on the quality of institutions and economic policies is taken from individual or aggregate components of the index published in the Economic Freedom of the World: 2000 Annual Report issued by the Frazer Institute. The index is a weighted average of the different composed indicators designed to identify the quality of institutional arrangements and policies in major areas. ${ }^{9}$

\footnotetext{
${ }^{6}$ Since we are interested in the effects of the historically realized REERs on growth and not in the investigation of their law of variation we prefer the above mentioned way of calculating it to ARCH or GARCH measures of volatility.

${ }^{7}$ Exchange rates are official rates with one exception. From the end of 1990 until 1995 for transition countries trading with the URSS (Czeck Republic, Estonia, Lithuania and Latvia) the mean monthly weighted exchange rate is calculated not by the official exchange rate, as the previous column, but by the black market exchange rate. This last value is published on the Italian Exchange Office (www.uic.it). From May 1995 there is only the russian rublo and the distinction between market and official exchange rate does not apply anymore.

${ }^{8}$ As remembered in section 2 Chapter 11 of the EU aquis asks for measures of convergence in exchange rate and economic policy which should lead to higher exchange stability and increase the likelihood of future accession to the MU.

${ }^{9} 1$ Size of Government: Expenditures, Taxes, and Enterprises A General government consumption spending as a percentage of total consumption B Transfers and subsidies as a percentage of GDP; C Government enterprises and investment as a percentage of GDP; D Top marginal tax rate (and income threshold to which it applies); i Top marginal tax rate (excluding applicable payroll taxes); ii Top marginal tax rate (including applicable payroll taxes) 2 Legal Structure and Security of Property Rights A Judicial independence. the judiciary is independent and not subject to interference by the government or parties in disputes; B Impartial court. a trusted legal framework exists for private businesses to challenge the legality of government actions or regulation; C Protection of intellectual property; D Military interference in rule of law and the political process; E Integrity of the legal system 3 Access to Sound Money
} 
Tables $3 \mathrm{a}$ and $3 \mathrm{~b}$ present synthetic comparisons of changes in the index in major areas for different subgroup of countries from 1990 to 2000 . They generally show i) a significant improvement and ii) a significantly higher reduction of heterogeneity for the subgroup of candidates transition countries relatively to transition non candidates, EU and OECD non EU countries.

If we look at differences between transition candidates and non candidates we find that candidates have a higher rate of growth in all considered indicators (2 percent against minus 12 percent in legal structure and property rights, 33 percent against 24 percent in access to sound money; 82 percent against 75 percent in regulation of credit, labour and business and 49 percent against 33 percent in the overall index of institutional quality). The increased homogeneity effect is much stronger. If we look at the overall index we find a reduction of 55 percent in the standard deviation of the overall index of institutional quality for transition candidates against an increase of 23 percent for transition non candidates compared with a reduction of 27 percent of EU countries and of 16 percent for OECD non EU countries.

Beyond these rates of change we find trace of a significant convergence of transition countries to the EU levels of above mentioned indicators.

Consider also that data are available for all candidates, but not for some non candidates, and that data availability is generally positively related with good performance. Therefore our candidate/non candidate differences are likely to be downward biased. While the level effect may be affected by reverse causation (it is ex ante higher institutional quality of candidates with respect to non candidates which causes admission and not viceversa) the rate of change effect is a more clear evidence of direct causation (after the "admission race" starts candidates improve their institutional quality more than non candidates). ${ }^{10}$

A closer inspection to components of the aggregate index show that, for transition countries, the institutional convergence of legal structure and security of property right and of banking system and financial markets (credit market regulation and freedom to open current account abroad) anticipates convergence of monetary policies and inflation. Quite interestingly, the improvement in the quality of institutions and economic policies generally anticipates the beginning of the negotiating process.

A Average annual growth of the money supply in the last five years minus average annual growth of real GDP in the last ten years; B Standard inflation variability in the last five years; C Recent inflation rate; D Freedom to own foreign currency bank accounts domestically and abroad 4 Freedom to Exchange with Foreigners A Taxes on international trade i Revenue from taxes on international trade as a percentage of exports plus imports ii Mean tariff rate iii Standard deviation of tariff rates; B Regulatory trade barriers i Hidden import barriers. no barriers other than published tariffs and quotas ii Costs of importing. the combined effect of import tariffs, licence fees, bank fees, and the time required for administrative red-tape raises the costs of importing equipment; $\mathrm{C}$ Actual size of trade sector compared to expected size; D Difference between official exchange rate and black market rate E International capital market controls i Access of citizens to foreign capital markets and foreign access to domestic capital markets ii Restrictions on the freedom of citizens to engage in capital market exchange with foreigners index of capital controls among 13 IMF categories 5 Regulation of Credit, Labor, and Business A Credit Market Regulations i Ownership of banks. percentage of deposits held in privately owned banks ii Competition. domestic banks face competition from foreign banks iii Extension of credit. percentage of credit extended to private sector iv Avoidance of interest rate controls and regulations that lead to negative real interest rates $\mathrm{v}$ Interest rate controls .interest rate controls on bank deposits and/or loans are freely determined by the market; B Labor Market Regulations i Impact of minimum wage. the minimum wage, set by law, has little impact on wages because it is too low or not obeyed ii Hiring and firing practices. hiring and firing practices of companies are determined by private contract iii Share of labor force whose wages are set by centralized collective bargaining iv Unemployment Benefits. the unemployment benefits system preserves the incentive to work; v Use of conscripts to obtain military personnel; C Business Regulations i Price controls. extent to which businesses are free to set their own prices ii Administrative conditions and new businesses. administrative procedures are an important obstacle to starting a new business iii Time with government bureaucracy. senior management spends a substantial amount of time dealing with government bureaucracy iv Starting a new business. starting a new business is generally easy v Irregular payments. irregular, additional payments connected with import and export permits, business licenses, exchange controls, tax assessments, police protection, or loan applications are very rare.

${ }^{10}$ Consider also that all ex communist countries are in these years under pressure of financial institutions (BERS, IMF) asking them for institutional reforms. Hence our candidates/non candidates measures evaluate in some way effects of the marginal pressure exerted by enlargement process in addition to the one of international financial institutions. 


\subsection{The model}

The theoretical benchmark for evaluating the effects of negotiations for EU accession is a standard MRW (1992) model with decreasing returns to scale in physical and human capital where country output (Y) is modeled as:

$\mathrm{Y}_{\mathrm{t}}=\mathrm{F}(\mathrm{K}, \mathrm{H}, \mathrm{AL})=\mathrm{K}_{\mathrm{t}}^{\alpha} \mathrm{H}_{\mathrm{t}}^{\beta}\left(\mathrm{A}_{\mathrm{t}} \mathrm{L}_{\mathrm{t}}\right)^{1-\alpha-\beta} \quad$ with $\alpha+\beta<1$

with $\mathrm{L}$ and $\mathrm{K}$ being the standard labour and physical capital inputs, $\mathrm{H}$ the stock of human capital, while $\mathrm{A}$ is a variable capturing all other factors affecting labour productivity.

Following Bagella-Becchetti-Hasan (2003) our hypothesis is that REER volatility and quality of institutions and monetary policies (the two variables affected by accession negotiations) are among these factors or:

$A_{(t)}=A_{K P(t)} A_{V(Q I R M P, R E E R V, \ldots)(t)}$

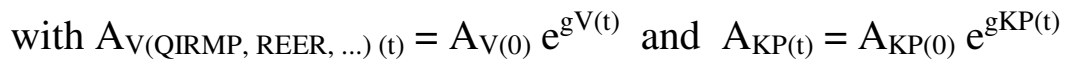

where $\mathrm{A}_{\mathrm{KP}(t)}$ is the traditional contribution to technological progress of innovation and $\mathrm{g}_{\mathrm{KP}}$ its rate of growth. $A_{V}$ therefore includes factors different from the former affecting labour productivity (and, among them, the quality of governance and of macroeconomic policies (QIRMP) and REER volatility) and $g_{\mathrm{V}}$ is its rate of growth.

With physical and human capital following the standard laws of motion and under the exogenous growth of the labour input ${ }^{11}$ we rewrite the production function in terms of output per efficiency units as $\mathrm{y}=\mathrm{k}^{\alpha} \mathrm{h}^{\beta}$ and can obtain the two standard growth equations:

$\dot{k}_{t}=s_{k} y_{t}-(n+g+\delta) k_{t}$

$\dot{h}_{t}=s_{h} y_{t}-(n+g+\delta) h_{t}$

where $\mathrm{g}=\mathrm{g}_{\mathrm{EPR}}+\mathrm{g}_{\mathrm{QI}}+\mathrm{g}_{\mathrm{KP}}$

By calculating steady state values of physical and human capital, substituting them into the production function and taking logs we obtain:

$$
\begin{aligned}
& \ln \left(\frac{Y_{t}}{L_{t}}\right)=c+\gamma_{1}\left[\ln \left(A_{V}\right)+g_{V} t\right]+\frac{\alpha}{1-\alpha-\beta} \ln \left(s_{k}\right)+\frac{\beta}{1-\alpha-\beta} \ln \left(s_{h}\right)+ \\
& -\frac{\alpha+\beta}{1-\alpha-\beta} \ln (n+g+\delta)
\end{aligned}
$$

$\mathrm{c}=\ln \left(\mathrm{A}_{\mathrm{KP}(0)}\right)+\mathrm{g}_{\mathrm{KP}} \mathrm{i}$ is the quasi-public good component of knowledge products and is therefore assumed constant across countries.

11 The exogeneity of labour force growth is a restrictive assumption which can be accepted considering that changes in per capita income on fertility affect labour force with lags which go beyond the time interval considered in our estimate (especially panel estimates). Moreover, we may also assume that with migration and partial international mobility of labour the effect of domestic fertility on the labour force is limited. 
Bagella-Becchetti-Hasan (2003) show that quality of institutional rules and macroeconomic policies and real effective exchange rate volatility $\left[\ln \left(A_{\text {OIMP }}\right)+g_{\text {PMMP }} t\right],\left[\ln \left(A_{\text {REERV }}\right)+g_{\text {RERRV }} t\right]$ may be seen as two specific components of the country specific factor $\left[\ln \left(A_{V}\right)+g_{V} t\right]$ augmenting the effects of labour input on levels and growth of real per capita GDP.

The growth equation of the model is obtained by showing that, in the proximity of the balanced growth path, $y$ converges to $y^{*}$ at the rate $(1-\alpha-\beta)(n+g) \equiv \lambda$ since the solution of the differential equation 12

$\mathrm{d} \ln (\mathrm{y}) / \mathrm{dt}=-\lambda\left[\ln (\mathrm{y})-\ln \left(\mathrm{y}^{*}\right)\right]$

is

$\ln \left(\mathrm{y}_{\mathrm{t}}\right)-\ln \left(\mathrm{y}^{*}\right)=\mathrm{e}^{-\lambda \mathrm{t}}\left[\ln \left(\mathrm{y}_{0}\right)-\ln \left(\mathrm{y}^{*}\right)\right]$

By adding $\ln \left(\mathrm{y}^{*}\right)-\ln \left(\mathrm{y}_{0}\right)$ to both sides and replacing $\ln \left(\mathrm{y}^{*}\right)$ we obtain:

$$
\begin{aligned}
& \ln \left(y_{t}\right)-\ln \left(y_{0}\right)=\left(1-e^{-\lambda t}\right) \frac{\alpha}{1-\alpha-\beta} \ln \left(s_{k}\right)+\left(1-e^{-\lambda t}\right) \frac{\beta}{1-\alpha-\beta} \ln \left(s_{h}\right)+ \\
& -\left(1-e^{-\lambda t}\right) \frac{\alpha+\beta}{1-\alpha-\beta} \ln (n+g+\delta)-\left(1-e^{-\lambda t}\right) \ln \left(y_{0}\right)
\end{aligned}
$$

The specification for econometric analysis becomes:

$$
\begin{aligned}
& \ln \left(\frac{Y}{L}\right)_{\mathrm{t}}-\ln \left(\frac{Y}{L}\right)_{0}=c^{\prime}+g_{V} t+\gamma_{1}\left[\ln \left(A_{V}\right)+g_{V} t\right]+c_{1} \ln \left(s_{k}\right)+ \\
& c_{2} \ln \left(s_{h}\right)+c_{3} \ln (n+g+\delta)+c_{4} \ln \left(\frac{Y}{L}\right)_{0}
\end{aligned}
$$

Interpretation of findings from the growth estimate in (15) may be affected by observational equivalence. Originally, the MRW estimation framework was adopted by the authors to test the (human capital augmented) Solow exogenous growth model, but Bernanke and Gurkaynak (2001) show that such estimation framework is consistent with any growth model that admits a balanced growth path and therefore is compatible also with suitable endogenous growth models.

The exogenous/endogenous growth issue has special interest when we interpret the results of our growth equation, given that the interpretation under the two perspectives is quite different.

Consider, however, that the distinction blurs once we introduce quality of institutions and macroeconomic policies as a factor of exogenous growth in our augmented Solow model. In that case our framework clearly suggest that policy matters for growth independently from the question whether what we measured correspond to traditional exogenous or endogenous growth models.

By arguing that REER volatility and quality of institutions and economic policies proxy important components of the A-factor which augments labour productivity and is uniquely responsible of further growth from the equilibrium point, we implicitly introduce the importance of institutions and policies also in the exogenous growth framework Bagella-Becchetti-Hasan (2003). ${ }^{13}$

\subsection{Econometric specification and selected variables}

12 This obviously implies that the speed of convergence differs across countries and is crucially influenced by the pace of labour augmenting A-factors.

13 Dowrick and Rogers (2002) implicitly share our view by arguing that "the Solow-Swann steady state is a moving target which grows at different rates in each country" and by adding that such growth depends on technical progress which "may well reflect unobserved policy and institutional differences". 
We extract our variables by combining information from the World Bank development indicators, the Penn World Tables, the indicators of institutional quality collected by the Frazer institute and UNESCO data on school enrollment and quality adjusted schooling years of the working population. The dependent variable $\mathrm{Y} / \mathrm{L}$ is calculated as real gross domestic product per workingage person, $\mathrm{L}$ is measured by the working age population (population aged between 15-64). $\mathrm{s}_{\mathrm{k}}$ is gross domestic investment over GDP and is calculated using values taken from Penn World Tables or, alternatively, World Bank data. ${ }^{14}$

Three different types of human capital proxies are considered in our estimates.

We first consider as proxies of human capital, measures of school enrollment ratios at different educational levels. $^{15}$

This variable, commonly used in most applied empirical work, has been strongly criticized since current enrollment ratios represent human capital investment of future and not of the current working class. A direct measure of the schooling years of the working population is then preferred to the former variable (Wossmann, 2003). As a second proxy of human capital we therefore consider average schooling years of the working population calculated by Barro and Lee (2000).

The limit of the schooling year variable is that it does not take into account differences in the quality of the educational system and of teaching across countries.

To take into account this problem we use as a third proxy of human capital, the Hanushek and Kimko's (2000) educational quality index, normalized by Wossmann (2003) for each country relative to the measure for the United States.

Another problem to consider in level and growth estimates on a sample which joins transition countries and the rest of the world is the need of taking into account the possibility of the occurrence of structural breaks in productivity of labor and physical capital in transition countries during and after the communist period.

The literature on transition economies identifies several sources of structural differences between ex communist countries and the rest of market economies, before and after the fall of the Berlin wall. Easterly-Fisher (1995) documents the presence of low productivity rates in the communist period for the low elasticity of substitution between factors of production, considering that, in the communist era the plan generated restrictions to capital mobility and services were considered unproductive. Campos and Coricelli (2002) highlight that significant differences in factors productivities might have been generated by widespread labour hoarding which was deemed

\footnotetext{
${ }^{14}$ Penn World Tables are the result of a United Nation International Comparison Project whose aim is to create information for consistent cross-country comparisons in time and space starting from price surveys of identical sets of good and services in different countries. One of the advantages in using PWT data is in the adoption of perpetual inventory methods which allows to obtain more reliable information on net investment. PWT data purpose is to obtain data which control for distorsions arising from comparing value based indicators across different industries. Such distortions may be of three types. First, measures based on comparisons between values of output and values of input, if not deflated by the specific (output and input) price indexes may create biases in comparisons across time. Second, heterogeneity in market structures across sectors generate dispersion of prices above the competitive price level. As a consequences, industry driven differences may be affected industry specific differences in competitive environments. Third, indicators should be adjusted for input quality adjustment. Indeed, a higher capital stock investment expenditure can conceal not just higher "quantity" of the same capital good, but higher, same or less "quantity" of a higher vintage capital good. To find a detailed discussion of the methodology and of the critical issues of PWTs see Heston-Summers (1988, 1991 and 1996) .

15 Usually we find measures of gross and net school enrollment ratios. The first is the ratio of total enrollment, regardless of age, to the population of the age group that officially corresponds to the level of education shown, the second is the ratio of children of primary school age who are enrolled in school. Although the net enrollment ratio is more precise because excludes overage students in an attempt to capture more accurately the system's coverage, we use the gross enrollment ratio because of the scarcity of data available for the net ratio.
} 
necessary to cope with uncertainty in the delivery of inputs (fulfill plan targets) and to maximize subsidies for the enterprise.

Other authors emphasise how low factor productivity may persist also in the transition period. A problem of mismatch may arise since human capital accumulated under the communist regime was highly specialized and not easily transferable (Boeri, 2000) with "too many rocket scientist, too few marketing experts" (Campos-Dabusinkas, 2001).

Consider also that, after the communist period, decline in participation rates and slight decline in gross school enrolment ratios may have affected GDP as well.

This is why we estimate as a first step level and growth equations by adding coefficient dummies and testing the hypothesis of structural differences between transition countries and the rest of the sample before and after the communist era. Results on structural breaks tests are not significant, omitted for reasons of space and available from the authors upon request.

Information on the distribution of the dependent variable and of regressors used in the econometric analysis is presented in table 3. The investment to GDP ratio from World Bank data ranges from 6 to 53 percent, while the dispersion of the Summers-Heston investment to GDP measure (where raw measures are adjusted for quality and imperfect competition effects) is higher as expected. The highest percentile of secondary school gross enrolment ratios exceeds unity since it divides secondary school population (which includes pupils above the respective age class) to the secondary school age class. Median values of gross secondary school and tertiary school enrolment ratios are respectively 48 and 10 percent.

\subsection{Econometric findings}

The econometric estimation starts with a baseline growth model (5) with panel data for 99 countries. The panel consists of 5 year average data for the period 1970-2000 so there are as many as 593 observations for each country in the panel. The baseline equation is the first column of Table 4.1. The additional equations in the table test for the importance of the variables relevant to accession, exchange rate volatility and the quality of institutions. Equations (2)-(4) show the effects of introducing our measure of exchange rate volatility and alternative measures of institutional quality. Equations (5)-(8) in the table repeat the same equations with a dummy variable for the enlargement period (i.e. the transition countries after the announcement).

The baseline estimates are consistent with our expectations. Joint significance of fixed effects is never rejected. The hypothesis test on restriction implied by the model is not rejected.

There is negative and significant convergence effect. Physical capital investment is highly significant while investment in human capital is not. Similar results with panel growth equations are found in Islam (1995). Although the human capital variable is not significant, the result is understandable. Since panel data mainly measure the within country effects of changes in regressors on the dependent variable, changes in human capital in over this period may have a small influence on growth. The strong and significant effects of human capital found in cross-section results are captured by panel fixed effects in these estimates.

The enlargement dummy is significant, except when we introduce the indexes of institutional development. The measure of exchange rate volatility is not quite twice as big as its standard error. Exchange rate volatility and institutional quality are not entered simultaneously because they are strongly correlated $(0.54)$

If we look at the economic magnitude of the transition effect we find that accession candidates have an overall 15 percent bonus rate of growth in each of the two five years spells in which we consider that preparation for accession affects their performance. This amount to a premium of more than 2.5 percent per year.

Overall, the global panel estimates in Table 4.1 provide some supportive evidence for the role of volatility and institutional quality on growth. However, the results are not all that powerful. Since the particular hypotheses of interest concern the effects of EU accession on growth, we also 
show estimated of the model with just the EU and accession countries included in the sample. The data set is much smaller with no more than 28 countries in the panel. Estimates of the same set of equations are shown in Table 4.2.

With the restricted data set, the baseline model estimates are not as strong. In particular, the coefficients on physical capital are insignificant and sometimes take on the wrong sign. In the global results the physical capital coefficients are strong and the human capital weak. In the Europe plus transition sample, the opposite is true.

The enlargement dummy is large and significant in the smaller sample but it disappears completely when either exchange rate volatility or a measure of institutional quality is included in the equation. This lends credence to the underlying argument of the paper that accession has an important influence on growth trough the two channels suggested.

\section{Conclusions}

A typical argument that policymakers and academicians quote in favour of EU economic integration or convergence toward monetary unions is that these processes reduce the impact of financial crises on real economy of participants or candidates. This intuition is though difficult to test empirically since we cannot compare the historical course of events with the counterfactual hypothesis (how the crisis would have impacted in absence of participation or candidacy to EU economic integration or monetary union?).

In this paper we illustrate an alternative path which may help to evaluate these effects considering that effective promotion of one's own candidacy to EU enlargement requires an improvement in institutional quality and has the consequence of a reduction of real effective exchange rate volatility in financial markets.

Even in this specific case a problem of reverse causation arises given that transition non candidates were not admitted to negotiations because of their ex ante inferior institutional quality and macroeconomic performance. Reverse causation is much less likely to occur if we look at rates of change. Successful participation to the admission race has in fact improved institutional quality and quality of macroeconomic policies more for transition candidates than for transition non candidates. If this occurs, and if these variable positively affects level and growth of GDP, we are more likely to conclude that enlargement had an impact on them.

Our empirical findings confirm these hypotheses. We find that transition countries which are candidates to the enlargement have a good performance in terms of institutional change and real effective exchange rate volatility (relatively better than transition non candidates) in the period going from the time in which we may reasonably consider they started to prepare to admission until the most recent data available. Since the institutional quality variable has strong and significant effects on levels and growth of real per capita GDP we are led to conclude that the institutional path followed toward enlargement has positively affected levels and growth for these countries. 
Table 1 Main steps toward closer economic integration and accession to EU for transition countries

\begin{tabular}{|c|c|c|c|c|c|c|c|}
\hline \multirow[t]{2}{*}{ Countries } & \multicolumn{2}{|c|}{$\begin{array}{l}\text { Trade \& cooperation } \\
\text { agreement }\end{array}$} & \multicolumn{2}{|c|}{ Europe agreements } & \multicolumn{2}{|c|}{$\begin{array}{l}\text { Interim europe } \\
\text { agreements }\end{array}$} & \multirow[t]{2}{*}{$\begin{array}{l}\text { Formal } \\
\text { demand for } \\
\text { admission }\end{array}$} \\
\hline & signed & in force & signed & in force & signed & in force & \\
\hline Bulgaria & 8-mag-90 & 1-nov-90 & 8-mar-93 & 1-mag-95 & $8-m a r-93$ & 31-dic-93 & $14-12-1995$ \\
\hline Czech Rep. & $\ldots$ & $\ldots$ & 4-ott-93 & 1-mag-95 & 16-dic-91 & 1-mar-92 & 17-01-1996 \\
\hline Estonia & 11-mag-92 & $1-\operatorname{mar}-93$ & 12-giu-95 & 1-feb-98 & & ... & 24-11-1995 \\
\hline Hungary & 26 -set-88 & 1-dic-88 & 16-dic-91 & 1-feb-94 & 16-dic-91 & 1-mar-92 & 31-03-1994 \\
\hline Latvia & 11-mag-92 & 1-feb-93 & 12-giu-95 & 1-feb-98 & $\ldots$ & $\ldots$ & 13-10-1995 \\
\hline Lithuania & 11-mag-92 & $1-f e b-93$ & 12-giu-95 & 1-feb-98 & $\cdots$ & $\ldots$ & 08-12-1995 \\
\hline Poland & 19 -set-89 & 1-dic-89 & 16-dic-91 & 1-feb-94 & 16-dic-91 & 1-mar-92 & 05-04-1994 \\
\hline Romania & 22-ott-90 & 1-mag-91 & $1-f e b-93$ & 1-mag-95 & 1-feb-93 & 1-mag-93 & 22-06-1995 \\
\hline Slovak Rep. & $\cdots$ & ... & 4-ott-93 & 1-feb-95 & 16-dic-91 & 1-mar-92 & 27-06-1995 \\
\hline Slovenia & 5-apr-93 & 1 -set-93 & 10-giu-96 & 1-feb-99 & 11-nov-96 & 1-gen-97 & 10-06-1996 \\
\hline
\end{tabular}

Legend: TCA: most favoured nation; EA: preferential treatment of export, formal commitment to closet economic and political integration; IEA: early implementation of the trade aspects of Eas.

Source: Temprano Arroyo, H. Feldman R.A., Selected transition and mediterranean countries: an institutional primer on EMU and EU accession, Economics of Transition 7(3) pp. 741-806 
Figure 1 Dynamics of export portfolio volatility for EUROZONE countries and transition candidates

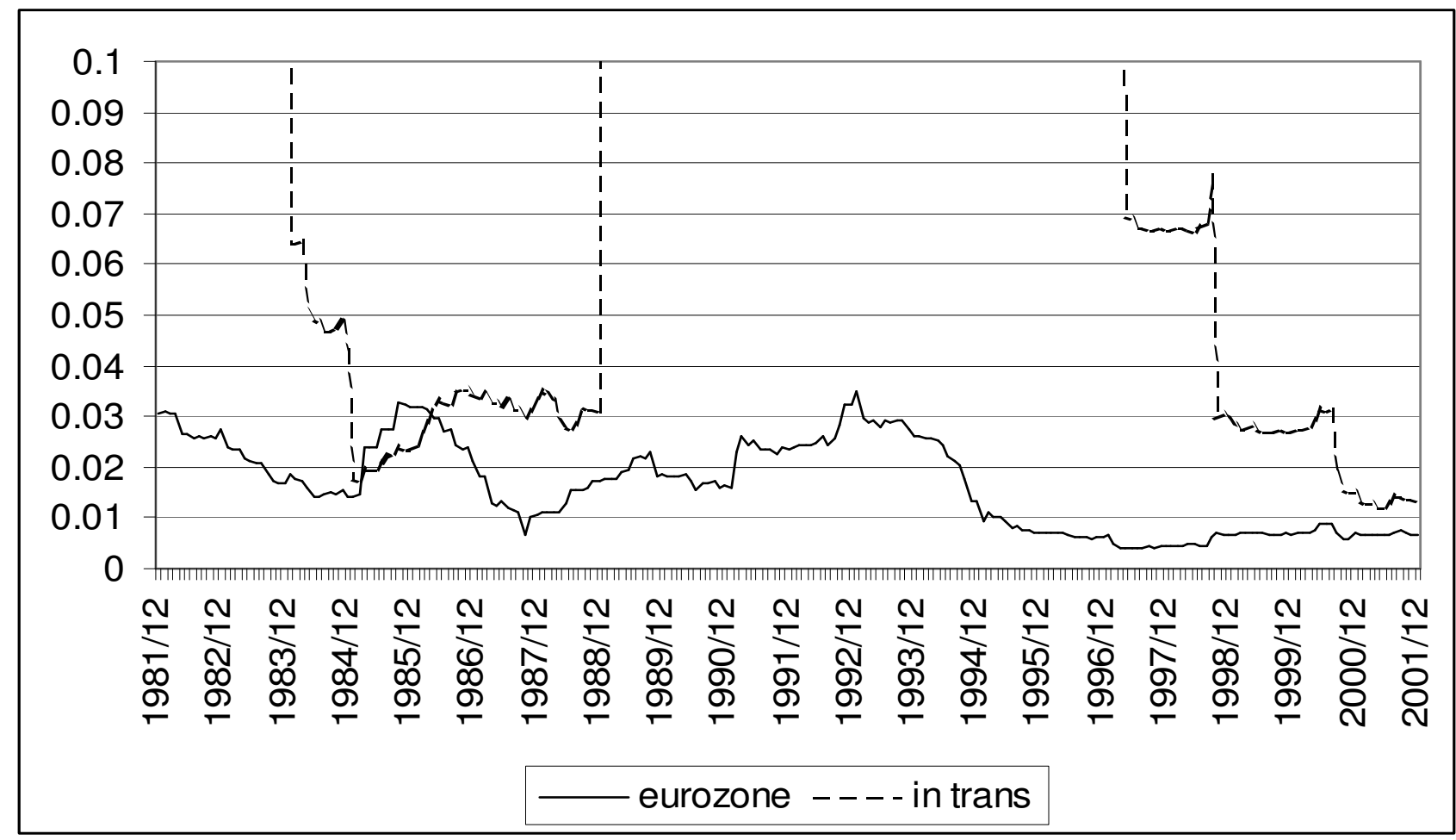


Table 2a 2000-1990 ratios for indicators of institutional quality and export portfolio volatility for EU, OECD non EU, transition candidates and non candidates - (2000 ratio - 1990 ratio $) / 1999$ ratio)

\begin{tabular}{|c|c|c|c|c|c|c|}
\hline & $\begin{array}{l}\text { Export portfolio } \\
\text { volatility* }\end{array}$ & Legstrupropri & Moneyacces & Freedomexc & Credlabbus & Indexfreed \\
\hline$\overline{\mathrm{UE}}$ & 0.75 & 0.137 & 0.110 & 0.100 & 0.188 & 0.084 \\
\hline OECD NON UE & 1.478 & 0.312 & 0.266 & 0.047 & 0.112 & 0.077 \\
\hline CANDIDATES & 0.644 & 0.022 & 0.334 & 0.451 & 0.825 & 0.494 \\
\hline NON CANDIDATES & & -0.125 & 0.235 & 0.488 & 0.758 & 0.334 \\
\hline
\end{tabular}

$*$ ratio of the 2003 value to the 1993 value

Table 2.b 2000-1990 ratios of the standard deviation of indicators of institutional quality for EU, OECD non EU, transition candidates and non candidates - (2000 ratio - 1990 ratio $) / 1999$ ratio)

\begin{tabular}{|l|r|r|r|r|r|}
\hline & Legstrupropri & Moneyacces & Freedomexc & \multicolumn{1}{l}{ Credlabbus } & Indexfreed \\
\hline UE & -0.115 & -0.554 & -0.544 & 0.214 & \\
\hline OECD NON UE & -0.288 & -0.455 & -0.433 & -0.277 \\
\hline CANDIDATES & -0.617 & -0.543 & -0.0134 & -0.149 & -0.362 \\
\hline NON CANDIDATES & -0.224 & -0.146 & & -0.553 \\
\hline
\end{tabular}

Group legend. Transition Non candidates: Albania, Armenia, Azerbaigian, Bosnia, Bulgaria, Croatia, Macedonia, Moldova, Romania, Russian, ,Tajikistan, Ukraine, Uzbekistan, Yugoslavia. Transition candidates (first phase enlargement) Czech R Estonia Hungary Latvia, Lithuania, Poland, Slovak, Slovenia. Transition candidates (second phase enlargement) Bulgaria Croatia, Romania. Variable legend: REER: real effective exchange rate (see Table 2 legend) Indexfreed: index of the quality of institutions and of economic policies. It is measured as a simple average of the following composed indicators 1 Size of Government: Expenditures, Taxes, and Enterprises A General government consumption spending as a percentage of total consumption B Transfers and subsidies as a percentage of GDP; C Government enterprises and investment as a percentage of GDP; D Top marginal tax rate (and income threshold to which it applies); i Top marginal tax rate (excluding applicable payroll taxes); ii Top marginal tax rate (including applicable payroll taxes) 2 Legstrupropri A Judicial independence. the judiciary is independent and not subject to interference by the government or parties in disputes; B Impartial court. a trusted legal framework exists for private businesses to challenge the legality of government actions or regulation; C Protection of intellectual property; D Military interference in rule of law and the political process; E Integrity of the legal system 3 Moneyacces A Average annual growth of the money supply in the last five years minus average annual growth of real GDP in the last ten years; B Standard inflation variability in the last five years; C Recent inflation rate; D Freedom to own foreign currency bank accounts domestically and abroad 4 Freedomexc A Taxes on international trade i Revenue from taxes on international trade as a percentage of exports plus imports ii Mean tariff rate iii Standard deviation of tariff rates; B Regulatory trade barriers i Hidden import barriers. no barriers other than published tariffs and quotas ii Costs of importing. the combined effect of import tariffs, licence fees, bank fees, and the time required for administrative red-tape raises the costs of importing equipment; C Actual size of trade sector compared to expected size; D Difference between official exchange rate and black market rate E International capital market controls i Access of citizens to foreign capital markets and foreign access to domestic capital markets ii Restrictions on the freedom of citizens to engage in capital market exchange with foreigners index of capital controls among 13 IMF categories 5 Credlabbus A Credit Market Regulations i Ownership of banks. percentage of deposits held in privately owned banks ii Competition. domestic banks face competition from foreign banks iii Extension of credit. percentage of credit extended to private sector iv Avoidance of interest rate controls and regulations that lead to negative real interest rates $\mathrm{v}$ Interest rate controls .interest rate controls on bank deposits and/or loans are freely determined by the market; B Labor Market Regulations i Impact of minimum wage. the minimum wage, set by law, has little impact on wages because it is too low or not obeyed ii Hiring and firing practices. hiring and firing practices of companies are determined by private contract iii Share of labor force whose wages are set by centralized collective bargaining iv Unemployment Benefits. the unemployment benefits system preserves the incentive to work; v Use of conscripts to obtain military personnel; C Business Regulations i Price controls. extent to which businesses are free to 
set their own prices ii Administrative conditions and new businesses. administrative procedures are an important obstacle to starting a new business iii Time with government bureaucracy. senior management spends a substantial amount of time dealing with government bureaucracy iv Starting a new business. starting a new business is generally easy v Irregular payments. irregular, additional payments connected with import and export permits, business licenses, exchange controls, tax assessments, police protection, or loan applications are very rare. 


\section{PROPERTY RIGHTS}

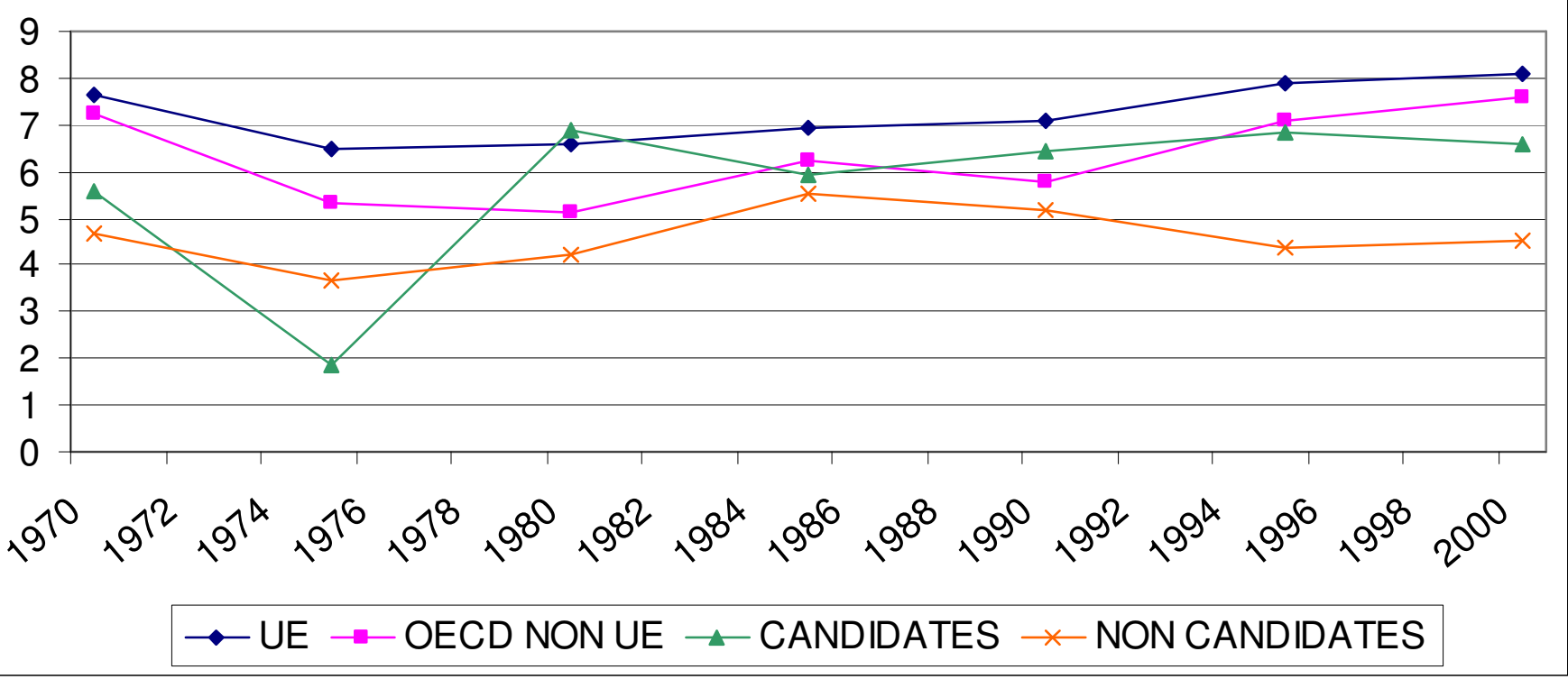

Figure 2 Legal Structure and Security of Property Rights for EU, OECD non EU, transition candidates and transition non candidates

Legal Structure and Security of Property Rights A Judicial independence. the judiciary is independent and not subject to interference by the government or parties in disputes; B Impartial court. a trusted legal framework exists for private businesses to challenge the legality of government actions or regulation; C Protection of intellectual property; D Military interference in rule of law and the political process; E Integrity of the legal system

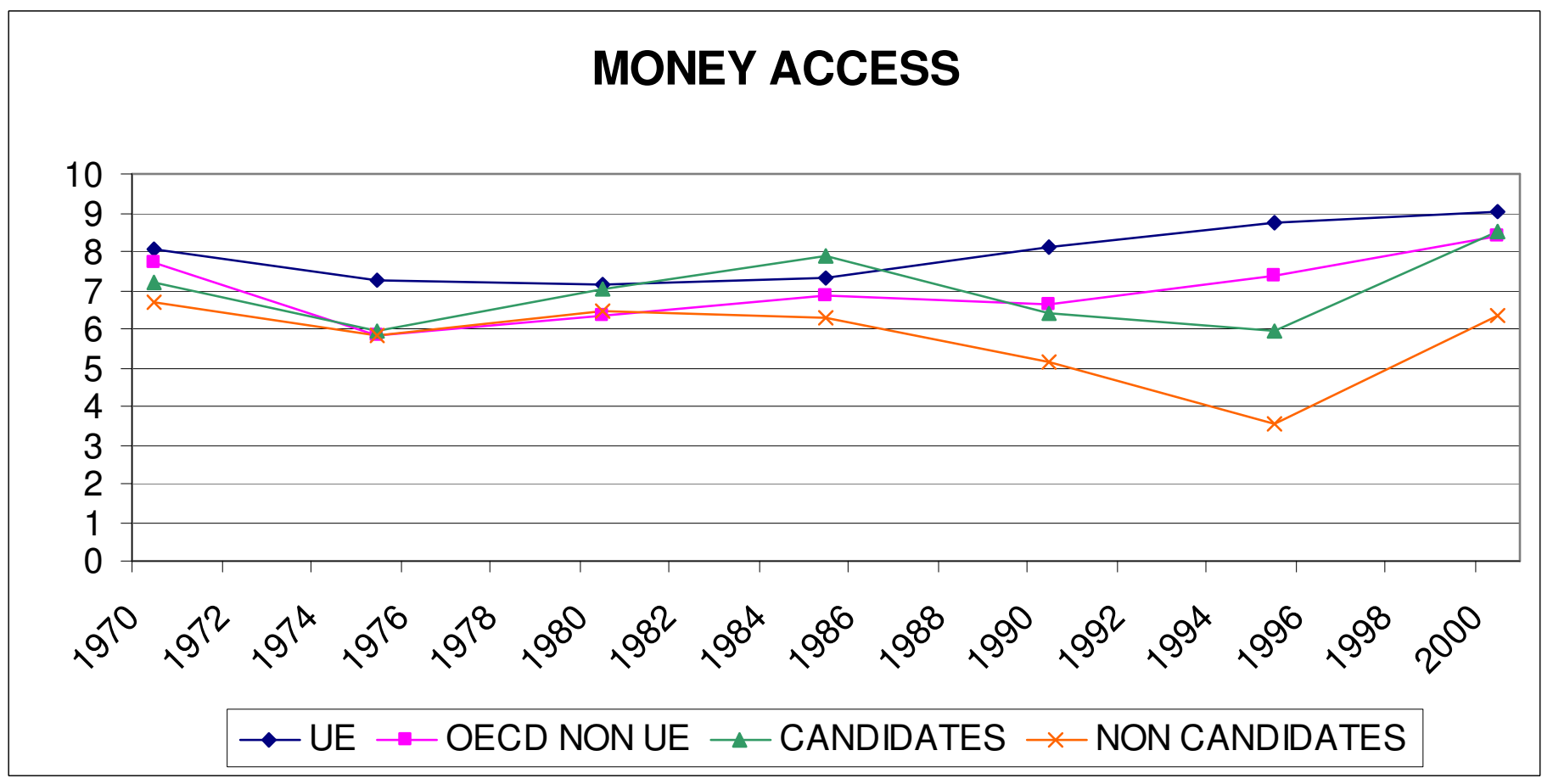

Figure 3 Access to sound money for EU, OECD non EU, transition candidates and transition non candidates

Freedom to Exchange with Foreigners A Taxes on international trade i Revenue from taxes on international trade as a percentage of exports plus imports ii Mean tariff rate iii Standard deviation of tariff rates; B Regulatory trade barriers $i$ Hidden import barriers. no barriers other than published tariffs and quotas ii Costs of importing. the combined effect of import tariffs, licence fees, bank fees, and the time required for administrative red-tape raises the costs of importing equipment; $\mathrm{C}$ Actual size of trade sector compared to expected size; D Difference between official exchange rate and black market rate $\mathrm{E}$ International capital market controls $\mathrm{i}$ Access of citizens to foreign capital markets and foreign access to 
domestic capital markets ii Restrictions on the freedom of citizens to engage in capital market exchange with foreigners index of capital controls among 13 IMF categories 


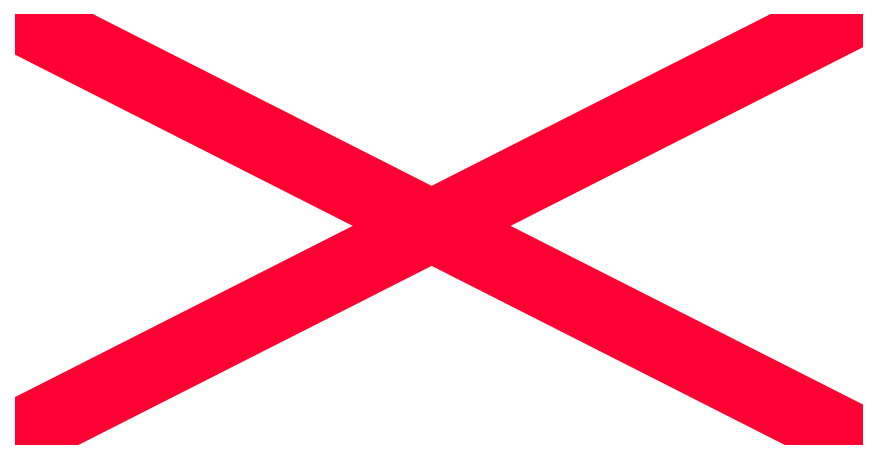

Figure 4 Freedom to Exchange with Foreigners for EU, OECD non EU, transition candidates and transition non candidates

Freedom to Exchange with Foreigners A Taxes on international trade i Revenue from taxes on international trade as a percentage of exports plus imports ii Mean tariff rate iii Standard deviation of tariff rates; B Regulatory trade barriers i Hidden import barriers. no barriers other than published tariffs and quotas ii Costs of importing. the combined effect of import tariffs, licence fees, bank fees, and the time required for administrative red-tape raises the costs of importing equipment; $\mathrm{C}$ Actual size of trade sector compared to expected size; D Difference between official exchange rate and black market rate $\mathrm{E}$ International capital market controls $\mathrm{i}$ Access of citizens to foreign capital markets and foreign access to domestic capital markets ii Restrictions on the freedom of citizens to engage in capital market exchange with foreigners index of capital controls among 13 IMF categories

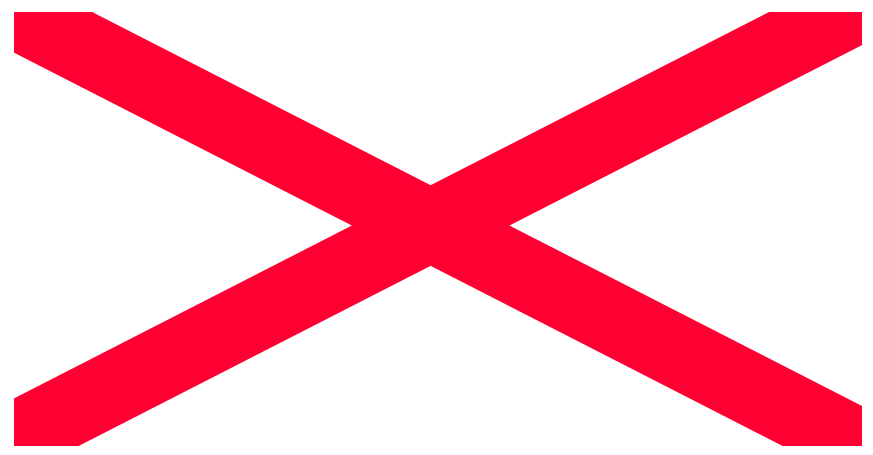

Figure 5 index of the quality of institutions and of economic policies for EU, OECD non EU, transition candidates and transition non candidates (for the definition of the index see Tables $2 \mathrm{a}-2 \mathrm{~b}$ legend) 
Table 3 Distribution of the regressors used in the econometric analysis

\begin{tabular}{|c|c|c|c|c|c|c|c|c|c|c|c|c|}
\hline CENTILE & NGD & GCAPFORM & CAPFIS & SCHOOLSECGRO & SCHOOLTERGRO & AVERSCHOL & SCHOOLQUA & QIRMP & MONEYACC & CREDLABUS & FREEDOMEX & REERV \\
\hline 5 & 0.054 & 0.062 & 0.035 & 0.050 & 0.003 & 1.100 & 0.533 & 3.440 & 1.271 & 3.091 & 2.099 & 0.000005 \\
\hline 10 & 0.057 & 0.070 & 0.056 & 0.100 & 0.006 & 1.900 & 0.591 & 3.770 & 3.292 & 3.848 & 3.314 & 0.000009 \\
\hline 20 & 0.062 & 0.103 & 0.096 & 0.173 & 0.017 & 2.700 & 0.791 & 4.040 & 4.862 & 4.484 & 3.948 & 0.000028 \\
\hline 30 & 0.067 & 0.117 & 0.120 & 0.230 & 0.030 & 3.230 & 0.796 & 4.500 & 5.310 & 4.845 & 4.480 & 0.000059 \\
\hline 40 & 0.070 & 0.139 & 0.143 & 0.351 & 0.054 & 3.800 & 0.834 & 4.880 & 5.740 & 5.160 & 5.110 & 0.000076 \\
\hline 50 & 0.074 & 0.160 & 0.172 & 0.486 & 0.105 & 4.700 & 0.873 & 5.050 & 6.060 & 5.285 & 5.430 & 0.000108 \\
\hline 60 & 0.076 & 0.187 & 0.192 & 0.612 & 0.162 & 5.780 & 0.933 & 5.300 & 6.266 & 5.536 & 5.800 & 0.000156 \\
\hline 70 & 0.078 & 0.204 & 0.213 & 0.755 & 0.203 & 6.640 & 1.040 & 5.500 & 6.738 & 5.700 & 6.600 & 0.000219 \\
\hline 80 & 0.082 & 0.245 & 0.239 & 0.872 & 0.245 & 7.740 & 1.165 & 6.020 & 7.560 & 6.180 & 6.930 & 0.000292 \\
\hline 90 & 0.086 & 0.316 & 0.284 & 0.940 & 0.300 & 8.770 & 1.270 & 6.730 & 8.550 & 6.641 & 8.074 & 0.000665 \\
\hline 95 & 0.093 & 0.420 & 0.312 & 1.002 & 0.359 & 9.970 & 1.377 & 7.145 & 9.185 & 6.908 & 8.447 & 0.000889 \\
\hline 99 & 0.145 & 0.532 & 0.664 & 1.217 & 0.565 & 11.900 & 1.541 & 8.400 & 9.538 & 7.250 & 9.350 & 0.007441 \\
\hline
\end{tabular}

Legend: $n g d$ : sum of the rate of growth of population, stock of capital depreciation and technological progess; Gcapform: gross capital formation over GDP (WB data); Capfis: Summers-Heston corrected investment/GDP ratio, Schoolsecgro. Gross secondary school enrolment ratio;

Schooltergro. Gross tertiary school enrolment ratio; Averschol average schooling of the working population ; Schoolqua: average schooling of the working population corrected for quality; QIRMP: Quality of institutional rules and of macroeconomic policies (see table 3 legend), Moneyacc: Access to Sound Money (see table 3 legend); Credlabus Regulation of Credit, Labor, and Business (see table 3 legend); Reerv: real effective exchange rate volatility (calculated as one year variance of REER monthly returns). 
Table 4.1 Growth equations: institutions, exchange rate volatility and enlargement in

\begin{tabular}{|c|c|c|c|c|c|c|c|c|}
\hline MRW & $\begin{array}{c}\text { Baseline } \\
\text { model }\end{array}$ & $\begin{array}{c}\text { Baseline } \\
\text { model + } \\
\text { REERV }\end{array}$ & \begin{tabular}{|c|} 
Baseline \\
model + \\
Inst var. 1
\end{tabular} & $\begin{array}{c}\text { Baseline } \\
\text { model }+ \\
\text { Inst var. } 2\end{array}$ & $\begin{array}{c}\text { Baseline } \\
\text { model + } \\
\text { dummy } \\
\text { enlarge- } \\
\text { ment } \\
\end{array}$ & $\begin{array}{c}\text { Baseline } \\
\text { model }+ \\
\text { REERV+ } \\
\text { dummy } \\
\text { enlargement }\end{array}$ & \begin{tabular}{|c} 
Baseline \\
model + Inst \\
var. $1^{+}$ \\
dummy \\
enlargement
\end{tabular} & $\begin{array}{c}\text { Baseline } \\
\text { model + Inst } \\
\text { var. } 2^{+} \\
\text {dummy } \\
\text { enlargement } \\
\end{array}$ \\
\hline \multirow[t]{2}{*}{$\operatorname{Ln}(Y / L(t o))$} & -0.152 & -0.181 & -0.221 & -0.157 & -0.155 & -0.186 & -0.220 & -0.160 \\
\hline & -7.84 & -5.50 & -8.21 & -5.11 & -8.02 & -5.72 & -8.19 & -5.20 \\
\hline \multirow[t]{2}{*}{$\ln \left(s_{k}\right)$} & 0.108 & 0.058 & 0.084 & 0.061 & 0.112 & 0.067 & 0.084 & 0.065 \\
\hline & 5.18 & 2.06 & 3.35 & 2.25 & 5.40 & 2.37 & 3.35 & 2.37 \\
\hline \multirow[t]{2}{*}{$\ln \left(s_{h}\right)$} & -0.026 & 0.059 & 0.036 & 0.027 & -0.025 & 0.060 & 0.036 & 0.027 \\
\hline & 0.02 & 1.55 & 0.03 & 0.72 & -1.25 & 1.59 & 1.33 & 0.70 \\
\hline \multirow{2}{*}{$\ln (n+g+d)$} & -0.252 & -0.162 & -0.211 & -0.160 & -0.262 & -0.195 & -0.213 & -0.174 \\
\hline & -5.11 & -2.30 & -3.67 & -2.65 & -5.33 & -2.75 & -3.66 & -2.86 \\
\hline \multirow[t]{2}{*}{ Lnmepr } & & -0.006 & & & & -0.005 & & \\
\hline & & -1.99 & & & & -1.75 & & \\
\hline \multirow[t]{2}{*}{ Incredlabus } & & & 0.248 & & & & 0.246 & \\
\hline & & & 4.04 & & & & 5.53 & \\
\hline \multirow[t]{2}{*}{ Lnindexfree } & & & & 0.066 & & & & 0.063 \\
\hline & & & & 1.74 & & & & 1.66 \\
\hline \multirow[t]{2}{*}{ Denlarg } & & & & & 0.158 & 0.160 & 0.021 & 0.103 \\
\hline & & & & & 2.65 & 2.80 & 0.23 & 1.47 \\
\hline \multirow[t]{2}{*}{ Constant } & 0.919 & 1.162 & 1.097 & 0.964 & 0.920 & 1.135 & 1.094 & 0.961 \\
\hline & 4.49 & 3.85 & 4.49 & 3.86 & 4.53 & 3.80 & 4.46 & 3.86 \\
\hline $\begin{array}{l}\mathrm{H}_{0} \text { : Joint } \\
\text { insignificance } \\
\text { of fixed } \\
\text { effects }\end{array}$ & $\begin{array}{r}3.80(0.0 \\
0)\end{array}$ & $2.18(0.00)$ & $2.77(0.00)$ & $2.39(0.00)$ & $3.91(0.00)$ & $2.31(0.00)$ & $2.76(0.00)$ & $2.40(0.00)$ \\
\hline F-test & $\begin{array}{r}1.66(0 . \\
00)\end{array}$ & $7.31(0.00)$ & $\begin{array}{r}19.59(0.0 \\
0)\end{array}$ & $\left.6.31(0.00)\right|_{2} ^{2}$ & $\begin{array}{r}27.05(0.0 \\
0)\end{array}$ & $7.54(0.00)$ & $16.29(0.00)$ & $5.64(0.00)$ \\
\hline $\mathrm{R}^{2}$ within & 0.20 & 0.11 & 0.22 & 0.08 & 0.13 & 0.21 & 0.22 & 0.09 \\
\hline $\begin{array}{l}\mathrm{H}_{0}:(1)+(2)=- \\
(3)\end{array}$ & \begin{tabular}{|r|}
$1.53(0.2$ \\
$1)$ \\
\end{tabular} & $2.69(0.10)$ & $1.84(0.17)$ & $\begin{array}{r}0.90 \\
(0.34) \\
\end{array}$ & $1.49(0.22)$ & $2.85(0.10)$ & $1.88(0.17)$ & $1.20(0.27)$ \\
\hline Countries & 99 & 81 & 91 & 91 & 99 & 81 & 91 & 91 \\
\hline Obs & 593 & 378 & 451 & 440 & 593 & 378 & 451 & 440 \\
\hline
\end{tabular}

\section{conditional convergence (world countries, five year average panel)}

Legend: Gcapform: gross capital formation over GDP (WB data); Schoolqua: average schooling of the working population corrected for quality; $n g d$ : sum of the rate of growth of population, stock of capital depreciation and technological progess; QIRMP: Quality of institutional rules and of macroeconomic policies (see table 3 legend), Credlabus Regulation of Credit, Labor, and Business (see table 3 legend); Reerv: real effective exchange rate volatility (calculated as one year variance of REER monthly returns).Denlarg: dummy taking value of one for transition candidates in 
Table 4.2 Growth equations: institutions, exchange rate volatility and enlargement in conditional convergence (EU plus communist countries, five year average panel)

\begin{tabular}{|c|c|c|c|c|c|c|c|c|}
\hline MRW & $\begin{array}{c}\text { Baseline } \\
\text { model }\end{array}$ & $\begin{array}{c}\text { Baseline } \\
\text { model + } \\
\text { REERV }\end{array}$ & \begin{tabular}{|c|} 
Baseline \\
model + \\
Inst var 1
\end{tabular} & \begin{tabular}{|c|} 
Baseline \\
model + \\
Inst var 2
\end{tabular} & \begin{tabular}{|c|} 
Baseline \\
model + \\
dummy \\
enlargeme \\
$\mathrm{nt}$
\end{tabular} & \begin{tabular}{|c|} 
Baseline \\
model + \\
REERV+ \\
dummy \\
enlargement
\end{tabular} & $\mid \begin{array}{c}\text { Baseline } \\
\text { model + Inst } \\
\text { var. 1+ } \\
\text { dummy } \\
\text { enlargement }\end{array}$ & \begin{tabular}{|c|} 
Baseline \\
model + Inst \\
var. $2+$ \\
dummy \\
enlargement
\end{tabular} \\
\hline \multirow{2}{*}{$\operatorname{Ln}\left(Y / L_{(t o)}\right)$} & -0.293 & -0.232 & -0.279 & -0.308 & -0.309 & -0.233 & -0.281 & -0.295 \\
\hline & -4.89 & -3.44 & -5.35 & -3.99 & -5.3 & -3.46 & -5.36 & -4.20 \\
\hline \multirow[t]{2}{*}{$\ln \left(s_{k}\right)$} & -0.073 & -0.096 & 0.009 & 0.098 & -0.047 & -0.084 & 0.011 & -0.068 \\
\hline & -1.36 & -1.43 & 0.18 & -1.18 & -0.89 & -1.22 & 0.21 & -1.17 \\
\hline \multirow[t]{2}{*}{$\ln \left(s_{h}\right)$} & 0.176 & 0.294 & 0.320 & 0.392 & 0.197 & 0.286 & 0.317 & 0.364 \\
\hline & 1.80 & 2.49 & 4.17 & 3.17 & 2.07 & 2.41 & 4.11 & 3.91 \\
\hline \multirow[t]{2}{*}{$\ln (n+g+d)$} & -0.073 & 0.042 & 0.037 & 0.057 & -0.109 & 0.013 & 0.053 & 0.010 \\
\hline & -0.90 & 0.47 & 0.49 & 0.64 & -1.36 & 0.14 & 0.66 & 0.10 \\
\hline \multirow{2}{*}{ Lnmepr } & & -0.031 & & & & -0.029 & & \\
\hline & & -3.99 & & & & -3.57 & 0.258 & \\
\hline \multirow[t]{2}{*}{ Incredlabus } & & & 0.238 & & & & 4.10 & \\
\hline & & & 4.31 & & & & & 0.082 \\
\hline \multirow[t]{2}{*}{ Lnindexfree } & & & & 0.101 & & & & 0.93 \\
\hline & & & & 1.16 & & & & \\
\hline \multirow[t]{2}{*}{ denlarg } & & & & & 0.133 & 0.047 & -0.044 & 0.037 \\
\hline & & & & & 2.77 & 1.08 & -0.69 & 0.69 \\
\hline \multirow[t]{2}{*}{ Constant } & 2.390 & 1.52 & 2.007 & 2.284 & 2.437 & 1.510 & 2.051 & 2.160 \\
\hline & 4.35 & 2.31 & 4.16 & 3.49 & 4.57 & 2.28 & 4.20 & 3.54 \\
\hline $\begin{array}{l}\mathrm{H}_{0} \text { : Joint } \\
\text { insignificance } \\
\text { of fixed } \\
\text { effects }\end{array}$ & $\begin{array}{r}5.74(0.0 \\
0)\end{array}$ & $3.84(0.00)$ & $3.14(0.00)$ & $2.13(0.00)$ & $5.73(0.00)$ & $3.39(0.00)$ & $2.93(0.00)$ & $5.53(0.00)$ \\
\hline F-test & $\begin{array}{r}5.74(0.0 \\
0)\end{array}$ & $3.84(0.00)$ & $\begin{array}{r}12.41(0.0 \\
0)\end{array}$ & $4.04(0.00)$ & $8.72(0.00)$ & $7.78(0.00)$ & $10.36(0.00)$ & $5.53(0.00)$ \\
\hline $\mathrm{R}^{2}$ within & 0.24 & 0.43 & 0.43 & 0.29 & 0.30 & 0.44 & 0.43 & 0.30 \\
\hline $\begin{array}{l}\mathrm{H}_{0}:(1)+(2)=- \\
(3)\end{array}$ & $0.04(.84)$ & $0.14(.71)$ & $7.69(.00)$ & $3.04(.09)$ & $0.18(.67)$ & $1.18(.28)$ & $7.84(.00)$ & $3.69(.05)$ \\
\hline Countries & 28 & 24 & 26 & 25 & 28 & 24 & 26 & 25 \\
\hline Obs & 136 & 97 & 112 & 109 & 136 & 97 & 112 & 109 \\
\hline
\end{tabular}

Legend: Gcapform: gross capital formation over GDP (WB data); Schoolqua: average schooling of the working population corrected for quality; $n g d$ : sum of the rate of growth of population, stock of capital depreciation and technological progess; QIRMP: Quality of institutional rules and of macroeconomic policies (see table 3 legend), Credlabus Regulation of Credit, Labor, and Business (see table 3 legend); Reerv: real effective exchange rate volatility (calculated as one year variance of REER monthly returns).denlarg: dummy taking value of one for transition candidates in 


\section{References}

Afxentiou, P. C., 2000, Convergence, the Maastricht Criteria, and Their Benefits, Economia Internazionale, v. 53, iss. 4, pp. 437-48

Alesina, A. and Perotti, R., 1994, The political economy of growth: a critical survey of the recent literature, World Bank Economic Review, 8 (3), pp.351-71.

Barro, Robert J. and Jong-Wha Lee, International Data on Educational Attainment: Updates and Implications, Oxford Economic Papers, 53,3, 541-563.

Barua, A., Kriebel, C. and Mukhopadhyay, T. [1991], "Information Technology and Business

Value: An Analytic and Empirical Investigation," University of Texas at Austin Working Paper, (May).

Baum, C. F. Caglayan, M. and Barkoulas, J. T., 2001, Exchange Rate Uncertainty and Firm Profitability, Journal of Macroeconomics, Vol. 23, No. 4.

Becchetti, L., Londono Bedoya, D.A., Paganetto, L., 2003, ICT investment, productivity and efficiency:evidence at firm level using a stochastic frontier approach, Journal of productivity analysis, forth

Bernanke B.S., Gurkaynak, R.S., 2001. Is growth exogenous ? taking Mankiw Romer and Weil seriously. NBER Working Paper no. 8365.

Bleaney M. Greenaway, D, 2001, The Impact of Terms of Trade and Real Exchange Rate Volatility on Investment and Growth in Sub-Saharan Africa Journal of Development Economics, 65, (2), pp. 491-500.

Boeri, T., 2000, Structural change, welfare systems, and labour reallocation: lessons from the transition of formerly planned economies, Oxford, Oxford University Press.

Buiter, W., Corsetti, G., and Pesenti, P., 1998, Financial Markets and European Monetary Cooperation. The lessons from the 92-93 crisis, with, 1998, Cambridge University Press

Caballero , RJ and Corbo V, " The effect of real exchange rate uncertainty on exports: Empirical Evidence”, 1989, The World Bank Economic Review, 3/2.

Campos F., Coricelli, F., 2002 Growth in transition: what we know , what we don't, and what we should, Journal of Economic Literature, 2002, 3, pp. 793-836

Campos F.,Dabuniskas, A., 2001, So many rocket scientist, so few marketing clerks,. Determinants of occupational change durino the Estonian transition, CERGE-EI discussion paper 59.

Corsetti, G., Pesenti, P., 1999, Stability, asymmetry and discontinuity: the launch of the European Monetary Union Brookings Papers on Economic Activity, 1999, v. 0, iss. 2, pp. 295-358

Cottani, Joaquim,Domingo F. Cavallo, and Muhammad Shahbaz Khan, "Real Exchange Rate Behavior and Economic Performance in LDCs", Economic Development and Cultural Change, 1990, 39, 61-76.

Darby, Julia et al., " The Impact of Exchange Rate Uncertainty on the Level of Investment", Economic Journal, 1999, 109, C55-C67.

De Grauwe, Paul. 1988. "Exchange Rate Variability and the Slowdown in Growth of International Trade.” International Monetary Fund Staff Papers 35 (March): 63-84.

De Melo, M., Denizer, C., and Gelb A., 1996, From plan to market: patterns of transition, World Bank Economic Review, 10,3, pp. 397-424.

Fischer, Sahay and Vegh, 1996a,

Devereux, M. B., Engel, C., Tille, C., 1999, Exchange Rate Pass-through and the Welfare Effects of the Euro, mimeo.

Dixit, A. and Pindyck , R., 1994, Investment Under Uncertainty, Princeton University Press.

Dollar, David, " Outward-Oriented Developing Economies Really Do Grow More Rapidly: Evidence from 95 LDCs, 1976-85", Economic Development and Cultural Change, 1992, 40, 523544. 
Durlauf, S.N.and Quah D.T., 1998, The new empirics of economic growth, Center for Economic Performance Discussion Paper N. 384.

Dwyer G.P. Lothian J.R., 2003, The Economics of International Monies in Research in Banking and Finance, forth.

Easterly, W., Islam, R.and Stiglitz, J., 2000, "Shaken and Stirred, Explain Growth Volatility," paper presented at the Annual World Bank Series of Development Economics

Efron, B., 1979, Bootstrap methods: another look at the jackknife, Annals of Statistics, 7, 1-26.

Efron, B. and Stein, C., 1981, The jackknife estimate of variance, Annals of Statistics, 9, 586-596.

Efron, B. and Tbishirani, R., 1986, Boostrap measures for standard errors, confidence intervals and other measures of statistical accuracy, Statistical Science, 1, 54-77.

Esfahani H.S. Ramirez M.T., 2003, Institutions, Infrastructure, and Economic Growth, Journal of

Development Economics, v. 70, iss. 2, pp. 443-77

Easterly, W. Fisher S., 1995, The Soviet Economic Decline, World Bank Economic Review 9(3): 341-371, 1995

Edwards E. Yeyati L., 2003, Flexible exchange rates as shock absorbers, NBER Working Paper n.

9867.

Froot, Kenneth A. and Klemperer, Paul D., 1989, Exchange Rate Pass-Through When Market

Share Matters, American Economic Review, September v. 79, iss. 4, pp. 637-54.

Gali, J. Perotti, R., 2003, Fiscal policy and monetary integration in Europe, Economic Policy, forth.

Ghura, Dhaneshaawar, and Thomas Grennes, "The Real Exchange Rate and Macroeconomic

Performance in Sub-Saharan Africa", Journal of Development Economics, 1993, 42, 155-174.

Giavazzi, F.; Pagano, M., 1994 The advantage of tying one's hands, in Monetary and fiscal policy.

Volume 1. Credibility, 1994, pp. 225-46, Cambridge and London: MIT Press,

Guerin, J. L. and Lahreche-Revil A., "Exchange Rate Volatilty and Growth", 2002, University of Amiens ( CRIISEA), TEAM-CNRS and CEPII.

Hall, R. E.; Jones, C. I., 1997, levels of economic activities across countries, American Economic Review, 87 (2), pp. 173-77

Hanushek Eric A. Kimko Dennis D., 2000. "Schooling, Labor-Force Quality, and the Growth of Nations," American Economic Review, Vol. 90 (5) pp. 1184-1208

Henderson, K., 2000, The Challenges of EU Eastward Enlargement, In tern a tional Pol i ti cs 3 7: 1 -17 .

Heston, A. and Summers, R., (1996). International price and quantity comparisons: potentials and pitfalls. American Economic Review, 86(2), May.

Kent C., Naja R., 1998, Effective real exchange rates and irrelevant nominal exchange rate regimes, Research Discussion paper n. 9811

Islam, N., 1995, Growth empirics: a panel data approach, Quarterly Journal of Economics, 110(4), pp.1127-1169.

Islam N., 2003, What have we learnt from the convergence debate ?, Journal of Economic Surveys, 17, 3, 309-361.

Jorgenson, D. W.; Stiroh, K. J., 2000, Raising the Speed Limit: U.S. Economic Growth in the Information Age, Brookings Papers on Economic Activity, 0(1), pp. 125-211

Kent C., Naja R., 1998, Effective real exchange rates and irrelevant nominal exchange rate regimes, Research Discussion paper n. 9811

King, R.G. and Levine, R., 1992, Finance and growth: Schumpeter might be right" The Quarterly Journal of Economics, August.

Klein P.G: Luu h. ,2003, Politics and productivity, Economic Inquiry, 41,(3), pp. 433-47

Knack, Stephen and Phillip Keefer, 1997, "Does Social Capital Have an Economic Payoff? A Cross-Country Investigation" Quarterly Journal of Economics 112, pp. 1251-88

Levine, R. and Renelt, D., 1992, A sensitivity analysis of cross-country growth regressions, American Economic Review, 82(4), 942-63. 
Mankiw, N.G., Romer, D. and Weil, D., 1992, A contribution to the empirics of economic growth, Quarterly Journal of economics, pp. 407-437.

Mauro, P., 1995, Corruption and growth, Quarterly Journal of Economics, 110 (3), pp.681-712.

Milgrom P., Roberts R., (1988), The Economics of Modern Manufacturing: Products, Technology and Organization, Stanford Center for Economic Policy Research Discussion Paper 136

Mundell, R. (1961), “A Theory of Optimum Currency Areas', American Economic Review, 51, 657-65

Obstfeld M., Rogoff K., 1995, The Mirage of Fixed Exchange Rates, The Journal of Economic Perspectives, Vol. 9, No. 4. (Autumn, 1995), pp. 73-96.

Pagano, M., 1993, Financial markets and growth: an overview, European Economic Review 37, pp. 613-622.

Persson, T. and Tabellini, G., 1994, Is inequality harmful for growth?, American Economic Review, 84:3, pp. 600-21.

Perotti, R., 1996, Growth, income distribution and democracy: what the data say, Journal of Economic Growth, 1, pp.149-87.

Serven, Luis, "Real exchange rate uncertainty and Private investment in developing countries", World Bank Policy Research Working Paper, 2000

Summers, Lawrence H. (1999), Reflections on managing global integration, The Journal of Economic Perspectives, Vol. 13, No. 2., pp. 3-18.

Qian, Ying and Panos Varangis, 1994, “ Does Exchange Rate Volatility Hinder Export Growth?”, Empirical Economics, 19, 371-396

Razin, O.; Collins, S. M., 1997, Exchange rate misalignment and growth, National Bureau of Economic Research Working Paper: 6174

Rodrik,

Serven, Luis, " Macroeconomic uncertainty and Private investment in LDCs: an empirical investigation”, World Bank Policy Research Working Paper 2035, 1998

"Real exchange rate uncertainty and Private investment in developing countries", World Bank Policy Research Working Paper , 2000

Summers, Robert and Heston, Alan. (1988). A new set of international comparisons of real product and price levels estimates for 130 countries, 1950-1985, Review of Income and Wealth, 34(1), March, 1-25.

Summers, Robert and Heston, Alan. (1991). The Penn World Table (Mark 5): an expanded set of international comparisons, 1950-1988, Quarterly Journal of Economics, 106(2), May, 327-68.

Svensson, Lars E.O. 1994. "Fixed Exchange Rates as a Means to Price Stability: What Have We Learned?" European Economic Review 38 (April): 447-68.

----. 1999. "Monetary Policy Issues for the Eurosystem." Working Paper 7177. Cambridge, Mass.: National Bureau of Economic Research (June).Temple, J., 1999, The new growth evidence, Journal of Economic Literature, 37, pp.112-156.

Temple, J., 1999, The new growth evidence, Journal of Economic Literature, 37, pp.112-156.

Temprano Arroyo, H. Feldman R.A., Selected transition and mediterranean countries: an institutional primer on EMU and EU accession

Economics of Transition 7(3) pp. 741-806

Qian, Ying and Panos Varangis, “ Does Exchange Rate Volatility Hinder Export Growth?”, Empirical Economics 1994, 19, 371-396

Woszmann. L., Specifying Human Capital, Journal of Economic Surveys, 2003, vol. 17, 3, pp. 239-270. 